\title{
Development of Scale to Measure Livelihood Security of Farmers Practicing Different Farming Systems in Southern Karnataka, India
}

\author{
N.V. Shwetha* and Y.N. Shivalingaiah \\ Department of Agricultural Extension, University of Agricultural Sciences, GKVK, \\ Bangalore-560065 \\ *Corresponding author
}

\section{A B S T R A C T}

Keywords

Relevancy,

Reliability,

Validity, Livelihood security

Article Info

Accepted:

07 October 2019

Available Online:

10 November 2019
The agricultural sector is the backbone of Indian economy. Over 58 per cent of rural Indians depending on agriculture for their livelihood and agriculture contribute around 17 to 18 per cent to the country's Gross domestic product. An attempt was made in the study to construct a scale to measure the livelihood security of farmers practicing different farming systems. The judges rating method was followed in the construction of livelihood security scale. The livelihood security scale developed was administered to 30 farmers of Doddaballapura taluk of Bengaluru rural district of Karnataka during 2019-20. The results revealed that nearly half $(40.00 \%)$ of the farmers belonged to average level of livelihood security, while 33.34 per cent of farmers belonged to better and 26.66 per cent of the respondents belonged to poor level of livelihood security.

\section{Introduction}

The agricultural sector is the backbone of Indian economy contributing majorly to the country's Gross Domestic Product (GDP). As on February 2018, it is estimated that over 58 per cent of rural Indians depend on agriculture for their livelihood and this sector contributes around 17 to 18 per cent to the country's GDP. The major source of livelihood in the country is agriculture. Agricultural development has received the highest priority in the programmes of planned change and generate higher income and also create adequate employment opportunities for the rural mass by maximizing the productivity not only in the field of agriculture but also in the field of off farm and allied enterprises with special importance on animal husbandry, pisiculture, small scale agro-industries and handicrafts through proper identification and development of indigenous knowledge and traditional skills. Traditional farming system practiced by farmers in our country are mainly based on 
centuries of experiences characterized by diversified farming involving crop production with one or more enterprises like dairy, sericulture, poultry, goat, sheep, bee-keeping and fisheries. Their main aims were to achieve stability in production, protect against weather changes, provide subsistence for the family and other environmental stresses.

In the recent years, the concept which has gave scientific touch to existing practices is farming system approach and also found ways and means to make it sustainable in changing world scenario.

At an aggregate level, it is appropriate to study the farming system in relatively homogeneous agro-climatic regions in keeping with natural endowments and factors, which are normally not subject to change.

Livelihood is the methods for individuals use to help themselves, to endure and to thrive. Livelihood is an outcome of why and how people organize to transform the environment to fulfil their needs through technology, labour, power, knowledge and social relations. Livelihoods are also shaped by the more extensive financial and political frameworks inside which they operate.

The gradual decline in farm land holding has become more difficult to produce required food and other agricultural products for the family. The situation is continued to weaken due to repeated failure of monsoons on one side and on the other side, due to increasing population and decrease in per capita availability of land.

Further, there is no scope for horizontal expansion of land and only vertical expansion is possible by integrating various farm components. Hence, the present study is taken up with the following specific objectives: To develop and standardize a scale to measure the livelihood security of farmers practicing different farming systems.

To know the livelihood security of farmers practicing different farming systems.

\section{Materials and Methods}

The study was conducted in Thirumagondanahalli, Gundumgere, Marahalli and Vaddarahalli villages of Doddaballapura district of Karnataka state during 2019.

Thirty farmers practicing different farming systems were personally interviewed using scale developed to measure their livelihood security. The collected data was scored and analysed using frequency and percentage.

\section{Development of a scale to measure livelihood security of farmers practicing different farming systems}

Livelihood security is operationally defined as "the ability of the farmers to earn by practicing different farming systems and spend their income on all basic and other necessaries which are essential for decent living. Further, it refers to the ability of the farmers to protect their capabilities, assets and activities which are essential for their livelihood". The method suggested by the Likert (1932) and Edwards (1969) in developing summated rating scale was followed through six stages viz., identification of dimensions, collection of items/statements, relevancy test, item analysis, reliability and validity.

\section{Identification of dimensions}

Six major dimensions related to livelihood security were identified based on review of literature and discussion with experts in the field of extension education, agricultural economics and agronomy. The identified 
dimensions are food and nutritional security, economic security, ecological security, social security, psychological security and physical security.

\section{Collection of items / statements}

A large number of draft statements on each dimension of livelihood security were collected based on review of literature, discussion with relevant specialists and researcher's own experience. These statements were carefully edited, revised and restructured to avoid ambiguity and duplication. Thus, 64 statements including negative statements were selected for further analysis.

\section{Relevancy analysis}

Sixty-four statements were mailed to 120 experts in the agricultural extension and other selected fields working in SAUs, CAU, ICAR institutions and Karnataka State Department of Agriculture etc., to critically evaluate the relevancy of each statement on five point continuum viz. Most Relevant (MR), Relevant(R), Somewhat Relevant (SWR), Less Relevant (LR) and Not Relevant (NR) with the score of 5, 4,3,2,1 respectively for positive statements and reverse for negative statements.

A total of 64 judges returned the questionnaires and duly filled 60 questionnaires were considered for further processing. From the data gathered, Relevancy Percentage, Relevancy weight age and Mean Relevancy Score were worked out for all the 64 statements using following formula:

Relevancy Percentage $(\mathrm{RP})=$

$$
\begin{aligned}
(\mathrm{MR} \times 5)+(\mathrm{R} \times 4)+(\mathrm{SWR} \times 3) & \\
& +(\mathrm{LR} \times 2)+(\mathrm{NR} \times 1) \times 100
\end{aligned}
$$

Maximum possible score

$$
\text { (i.e. } 60 \times 5=300 \text { ) }
$$

Relevancy Weightage (RW)

$=(\mathrm{MR} \times 5)+(\mathrm{R} \times 4)+(\mathrm{SWR} \times 3)$

$+(\mathrm{LR} \times 2)+(\mathrm{NR} \times 1)$

Maximum possible score

(i.e. $60 \times 5=300$ )

Mean Relevancy Score (MRS)

$=(\mathrm{MR} \times 5)+(\mathrm{R} \times 4)+(\mathrm{SWR} \times 3)$

$$
+(\mathrm{LR} \times 2)+(\mathrm{NR} \times 1)
$$

Number of judges responded

$$
\text { (i.e. 60) }
$$

Accordingly statements having relevancy percentage of equal and more than 85.00 per cent, relevancy weight age of equal and more than 0.85 and mean relevancy score of equal and more than 4.25 were considered for the inclusion in item analysis. Thus, 39 statements were retained out of 64 statements and these statements were considered for further processing and suitably modified as per the comments of experts wherever applicable.

\section{Item analysis}

To delineate the statements based on the extent to which they can differentiate the statements about Livelihood security scale, item analysis was carried on the statements selected in the first stage. Thirty farmers were selected from non-sample area and the respondents were asked to indicate their extent of livelihood security for each statement on a five point continuum ranging from "Very Greater Extent" to "Very Least Extent".

The scoring pattern adopted was 5 to 1 , in which 5 score to very greater extent response, 4 to great extent, 3 score to moderate extent response, 2 to least extent and 1 to very least extent response for the positive statement, in case of negative statement scoring pattern was reversed. Based upon the total scores, the respondents were arranged in descending 
order. The top 25 per cent of the respondents with their total scores were considered as high group and the bottom 25 per cent as low group.

These two groups provide criterion groups in terms of evaluating the individual statements suggested by Edwards (1969). 't' value was calculated for each of the statement by using the following formula:

$$
t=\frac{\bar{X}_{H}-\bar{X}_{L}}{\sqrt{\frac{\sum\left(X_{H}-\bar{X}_{H}\right)^{2}+\sum\left(X_{L}-\bar{X}_{L}\right)^{2}}{n(n-1)}}}
$$

Where

$$
\begin{aligned}
& \sum\left(X_{H}-\bar{X}_{H}\right)^{2}=\sum X_{H}{ }^{2}-\frac{\left(\sum X_{H}\right)^{2}}{n} \\
& \sum\left(X_{L}-\bar{X}_{L}\right)^{2}=\sum X_{L}^{2}-\frac{\left(\sum X_{L}\right)^{2}}{n}
\end{aligned}
$$

Where,

$\mathrm{XH}=$ Individual scores in the high group

$\overline{\mathrm{X}} \mathrm{L}=$ Individual scores in the low group

$\sum \mathrm{x} 2 \mathrm{H}=$ Sum of squares of the individual score on a given statement for high group

$\sum \mathrm{x} 2 \mathrm{~L}=$ Sum of squares of the individual score on a given statement for low group

$\mathrm{n}=$ Number of respondents in each group

$\sum=$ Summation

$\mathrm{t}=$ Extent to which a given statement differentiates between the high and low group

After computing the ' $t$ ' value for all the 39 statements, statements with ' $t$ ' value equal and greater than 2.145 were finally selected and included in the livelihood security scale, where all the 39 statements were significant at 5 percent.

\section{Standardization of scale}

The reliability and validity was ascertained for standardization of the scale.

\section{Reliability of the scale developed}

Split half method developed by Brown prophecy was employed to study the reliability of the tool. The reliability coefficient (rII) of the tool was found to be 0.828 , which is higher than the standard of 0.70 , indicating the constructed livelihood security scale was highly reliable and dependable in its measurement.

\section{Validity of the scale}

The data were subjected to statistical validity, which was found to be 0.95 for livelihood security scale, which is higher than the standard of 0.70 . Hence, the validity coefficient was found to be high and it seemed reasonable to accept the scale as a valid measure of the livelihood security.

\section{Administering the scale and method of scoring}

The livelihood security scale consists of 39 statements and the responses on extent of livelihood security were obtained on a fivepoint continuum representing 'very greater extent', 'greater extent', 'moderate extent', 'least extent' and 'very least extent' assigning a weight age of 5,4,3,2, and 1 respectively for positive statements and scoring was reversed for negative statements. The livelihood security score was calculated by adding up the scores obtained by the respondents on all 39 statements. The livelihood security score of this scale is ranging from a minimum of 39 and maximum of 195. The respondents were given their level of livelihood security for the 39 statements included in the scale (Table 1). 
Table.1 Scale to measure livelihood security of farmers practicing different farming systems

\begin{tabular}{|c|c|c|c|}
\hline $\begin{array}{l}\text { Sl. } \\
\text { No. }\end{array}$ & Statements & R.P & M.R.S \\
\hline I & Food and nutritional security & & \\
\hline 1. & Food in some kind is available throughout the year & 87.66 & 4.38 \\
\hline 2. & Quality of food available to my family is good & 88.66 & 4.43 \\
\hline 3. & A balanced food to family members is affordable & 89.33 & 4.46 \\
\hline 4. & $\begin{array}{l}\text { Quantity of the food items consumed by the household members is not } \\
\text { sufficient }\end{array}$ & 85.66 & 4.28 \\
\hline 5. & $\begin{array}{l}\text { Food grains provided through public distribution system is a major means } \\
\text { of livelihood security }\end{array}$ & 86.00 & 4.30 \\
\hline 6. & Different farming systems provide broad range of food items & 90.00 & 4.50 \\
\hline 7. & Diversified farming systems results in availability of balanced diet & 87.00 & 4.35 \\
\hline II & Economic security & & \\
\hline 1. & $\begin{array}{l}\text { The farming systems adopted by me results in optimum utilization of } \\
\text { resources }\end{array}$ & 91.66 & 4.58 \\
\hline 2. & $\begin{array}{l}\text { The farming system adopted is best possible to get maximum farm } \\
\text { productivity and income }\end{array}$ & 86.00 & 4.30 \\
\hline 3. & $\begin{array}{l}\text { Diversified farming system can enhance overall farm productivity that } \\
\text { leads to economic security }\end{array}$ & 88.33 & 4.43 \\
\hline 4. & $\begin{array}{l}\text { Cost of production could be minimized by practicing different farming } \\
\text { systems }\end{array}$ & 89.33 & 4.46 \\
\hline 5. & $\begin{array}{l}\text { Practicing different farming systems provides greater opportunity to } \\
\text { produce variety of products from agriculture and allied enterprises }\end{array}$ & 86.00 & 4.30 \\
\hline 6. & $\begin{array}{l}\text { Efficient utilization of land is possible through adoption of diversified } \\
\text { farming }\end{array}$ & 90.33 & 4.51 \\
\hline 7. & Practicing different farming systems results in higher benefit-cost ratio & 85.33 & 4.26 \\
\hline 8. & $\begin{array}{l}\text { My farming system adequately protect against risk and uncertainties of the } \\
\text { farm yield. }\end{array}$ & 87.66 & 4.38 \\
\hline 9. & Combining different farm components doesn't stabilize my farm income* & 85.00 & 4.25 \\
\hline 10. & Reasonable saving of earnings was possible from my farming system & 85.00 & 4.25 \\
\hline 11. & $\begin{array}{l}\text { Higher income generation is assured through marketing of various products } \\
\text { at various seasons act as a means of better livelihood }\end{array}$ & 87.33 & 4.36 \\
\hline 12. & $\begin{array}{l}\text { Overcoming stress condition was possible with dairy/sheep/goat rearing in } \\
\text { my farming system }\end{array}$ & 88.33 & 4.41 \\
\hline III & Ecological security & & \\
\hline 1. & Farming diversification improves water use efficiency & 89.66 & 4.48 \\
\hline 2. & Diversified farming system promotes recycling of farm waste & 91.33 & 4.56 \\
\hline 3. & $\begin{array}{l}\text { Practicing of diversified farming in my farm reduces vulnerability to } \\
\text { adverse climatic conditions }\end{array}$ & 85.00 & 4.25 \\
\hline 4. & $\begin{array}{l}\text { Different farming systems promotes the complimentary interaction of } \\
\text { different farm components }\end{array}$ & 92.33 & 4.61 \\
\hline 5. & $\begin{array}{l}\text { Maintaining sustainable soil fertility and soil health is possible with my } \\
\text { farming system }\end{array}$ & 87.66 & 4.38 \\
\hline IV & Social security & & \\
\hline 1. & Practicing different farming systems provides good recognition to me in the & 86.00 & 4.30 \\
\hline
\end{tabular}




\begin{tabular}{|c|c|c|c|}
\hline & society & & \\
\hline 2. & $\begin{array}{l}\text { Adopting diversified farming ensures good linkage with extension agencies } \\
\text { like DOA, DOH etc., }\end{array}$ & 87.33 & 4.36 \\
\hline 3. & Practicing diversified farming improves cosmopoliteness among farmers & 89.00 & 4.45 \\
\hline 4. & $\begin{array}{l}\text { My diversified farming systems ensures employment to the farm family } \\
\text { members round the year }\end{array}$ & 88.00 & 4.40 \\
\hline 5. & It integrates all land based activities & 88.00 & 4.40 \\
\hline $\mathbf{V}$ & Psychological security & & \\
\hline 1. & $\begin{array}{c}\text { Practicing diversified farming helps in improving my knowledge and skills } \\
\text { in farming }\end{array}$ & 85.00 & 4.25 \\
\hline 2. & $\begin{array}{c}\text { Experience in diversified farming gives me the confidence to try new ideas } \\
\text { in my farm }\end{array}$ & 85.00 & 4.25 \\
\hline 3. & $\begin{array}{l}\text { Diversified farming enhances my confidence level so that I can interact } \\
\text { with others easily }\end{array}$ & 86.66 & 4.33 \\
\hline 4. & $\begin{array}{c}\text { Diversified farming has created demand among farmers to visit my farm } \\
\text { and seek my advice regarding new things }\end{array}$ & 85.00 & 4.25 \\
\hline 5. & $\begin{array}{c}\text { Following diversified farming in your area, you are treated as leader in } \\
\text { society }\end{array}$ & 85.00 & 4.25 \\
\hline 6. & Diversified farming systems gives me higher satisfaction & 89.33 & 4.46 \\
\hline VI & Physical security & & \\
\hline 1. & $\begin{array}{c}\text { Diversified farming increases possibilities to possess a own house/new } \\
\text { house }\end{array}$ & 89.33 & 4.46 \\
\hline 2. & The land owned provides greatest prestige in the society & 90.00 & 4.53 \\
\hline 3. & Possess farm machineries as a means of security & 86.66 & 4.33 \\
\hline 4. & Possess a bore well for irrigation purpose to grow commercial crops & 87.66 & 4.38 \\
\hline
\end{tabular}

Table.2 Overall livelihood security of the farmers practicing different farming systems

\begin{tabular}{|c|c|c|c|}
\hline \multirow{2}{*}{ Sl.No. } & Categories & \multicolumn{2}{|c|}{ Livelihood security } \\
\cline { 2 - 4 } & & Number & Per cent \\
\hline $\mathbf{1}$ & Poor $(<177.29$ score $)$ & 08 & 26.66 \\
\hline $\mathbf{2}$ & Average $(177.29-185.57$ score $)$ & 12 & 40.00 \\
\hline $\mathbf{3}$ & Better $(>185.57$ score $)$ & 10 & 33.34 \\
\hline & Total & 30 & 100 \\
\hline
\end{tabular}

Mean $=181.43$, Standard deviation $=8.27$

Higher score on this scale indicates that the respondents have higher level of livelihood security. The livelihood security scale developed was administered to 30 farmers in the villages of Doddaballapura taluk of Bangalore rural district in Karnataka state.

The minimum and maximum scores obtained by farmers practicing different farming system were 39 and 195 respectively. Based on the mean and standard deviation the livelihood security of farmers was categorized into poor, average and better.

\section{Overall livelihood security of the farmers practicing different farming systems}

The result from Table 2 shows that 40.00 per cent of the farmers had average level of livelihood security followed by 33.34 per cent of the farmers had high level of livelihood security and 26.66 per cent of them had poor 
level of livelihood security. The reason for the observed trend was that they are practicing different combination of enterprises like agriculture, dairy, horticulture etc. instead of opting for any single enterprise. Hence, they are obtaining constant income and regular employment throughout the year. The findings are in conformity with Yashodhara (2015) and Mamathalakshmi (2013).

The livelihood security scale developed is found to be reliable and valid; hence, it can be used to measure the livelihood security of farmers practicing different farming system. The developed scale can be used by researchers to measure the livelihood security of the farmers. The developed livelihood security scale was administered by researcher to 30 farmers of Doddaballapur taluk.

It was found that majority (73.34\%) of the farmers had average to high level of livelihood security. It can conclude that the scale developed is useful in explicitly measuring the livelihood security of farmers practicing different farming systems.

\section{References}

Edward, L., 1969, The techniques of Attitude scale construction. VIkils, Feger and Simons Pvt. Ltd., 9, Sport Road, Ballard Estate, Bombay.

Likert, R., 1932, A technique for the measurement of attitudes. Arch. Psychology, No. 140.

Mamathalakshmi, N., 2013, An analysis of livelihood security among agricultural labourers in Karnataka. Ph.D. (Agri.) Thesis (Unpub.), Univ. Agric. Sci., Bangalore.

Yashodhara, B., 2015, A Comparative analysis of livelihood status in irrigated and rainfed farming situations in central dry zone of Karnataka. Ph.D. (Agri.) Thesis (Unpub.), Univ. Agric. Sci., Bangalore.

\section{How to cite this article:}

Shwetha, N.V. and Shivalingaiah, Y.N. 2019. Development of Scale to Measure Livelihood Security of Farmers Practicing Different Farming Systems in Southern Karnataka, India. Int.J.Curr.Microbiol.App.Sci. 8(11): 521-527. doi: https://doi.org/10.20546/ijcmas.2019.811.064 